\title{
Crime Control or Public Service? An Officer's Perception of his/her Occupational Role and its Effect on the Likelihood of on the Job Assault
}

\author{
Peter W. Liu \\ Monmouth University \\ 400 Cedar Ave, West Long Branch, NJ 07764, USA \\ John A. Shjarback \\ University of Texas at El Paso \\ 500 W University Ave, El Paso, TX 79968, USA
}

\begin{abstract}
The current research extends the study of assaults on police officers to the individual-level, examining whether the influences of either aggressive law enforcement or community policing ideologies contribute to police victimization. We employ a cross-sectional survey questionnaire, using a sample of 133 municipal law enforcement officers from eight departments throughout four New Jersey counties. Findings from an ordinary least squares (OLS) regression reveal that officers' subjective outlooks are, indeed, correlated with physical assaults. Policy/practical implications and directions for future research are also discussed.
\end{abstract}

The dangers associated with police work differentiate the occupation from most others. Due to the nature of the job, police officers are put at a heightened risk of personal victimization. According to the FBI's Uniform Crime Report (UCR), 54,774 law enforcement officers were assaulted in the line of duty in 2011 (FBI, 2012a). ${ }^{1}$ These assaults occurred at a rate of 10.2 per 100 sworn officers. The consequences stemming from assaults on police are diverse, negatively affecting an officer and his/her family, other fellow officers, and straining policecommunity relationships. Victimization can cause both physical injuries, resulting in lost wages and work hours, and psychological troubles such as posttraumatic stress disorder (Brandl \& Stroshine, 2012; Maguen et al., 2009). These effects translate into financial and emotional costs on the family and the department as a whole. Given the scope of the problem and the repercussions associated with it, it is no wonder why assaults are such a concern for police administrators and individual officers alike.

Unfortunately, not much is known about the etiology of assaults on police officers. The large majority of research on the topic appears to be descriptive in nature. Broad characteristics of injured officers and their assailants, the most dangerous calls for service, and community-level correlates are a few examples of the types of knowledge that have been discovered. Although this information is helpful, it does little to uncover the root causes of officer victimization. Physical altercations between officers and their assaulters often arise during verbal interactions between both parties. Something happens during the course of these interactions where events escalate into violent confrontations. For this reason, research must devote attention to the individual-level and focus on attributes of officers, assailants, or both. After a review of the literature, the influence of officers' policing styles may be a good place to start (see Kaminski, 2004; Kaminski, Jefferis, \& Gu, 2003).

The purpose of the current study is to extend the research on the assaults of police officers to the individual-level. More specifically, it aims to shed light on whether the influences of either aggressive law enforcement or community policing ideologies contribute to police victimization. Do an officer's perception of his/her occupational role (i.e. crime control vs. public service) and attitude/opinion towards citizens influence the likelihood of on the job assault? In order to answer the aforementioned questions, we employ survey research to patrol officers in the field. A sample of 133 municipal law enforcement officers from eight departments throughout four New Jersey counties is used to test our hypotheses. 


\section{Theoretical Framework}

\section{Assaults on Police Officers}

Meyer, Magedanz, Dahlin, \& Chapman (1981) characterize assaults on police officers into three main categories: general, ambush, and robbery-related. The three types greatly differ and are distinct in their origins and situational characteristics.

Ambush assaults are usually premeditated attempts to cause harm to officers, while robbery-related assaults develop out of one's attempt to avoid capture. General assaults on police are most common, whereas ambush and robbery-related assaults are relatively rare. Because they dominate the frequencies of occurrence, general police assaults are the primary focus of this research.

General police assaults transpire during the confrontation between an officer and a citizen. These types of assaults are preceded by much interaction and verbal, nonphysical communication between both parties. When an assault does take place, it is usually not the result of a rational or calculated decision on the part of the assailant. Instead, it is an impulsive and unplanned event (Meyer et al., 1981; Meyer, Magedanz, Kieselhorst, \& Chapman, 1979). Evidence attesting to the spontaneity of these events can be seen by the methods used by assaulters intending to inflict injury on officers. Statistics from the FBI's 2011 Law Enforcement Officers Killed and Assaults (LEOKA) report show that 79.9 percent of officers who were assaulted in the line of duty were attacked with personal weapons (e.g., hands, fists, or feet) (FBI, 2012a). This high percentage of assaults due to personal weapons is consistent across official and self-report data, and the proportion of assaults by personal weapons has been stable across the LEOKA reports since its inception.

Scholars have long theorized about the etiology of assaults on police officers. Most of the theoretical explanations focus on a combination of conflict, subcultural, and symbolic interactionist perspectives (see Boylen $\&$ Little, 1990). For example, police are seen as the unwitting participants in a conflict where they are perceived to exercise authority in support of the "social interests" in which they are aligned (Kieselhorst, 1974; Manning, 1980; Muir, 1980; Sherman, 1980). The "subculture of violence" among particular groups, such as lower class males, has been used to explain heightened levels of physical reactions/responses to confrontations (Miller, 1958; Wolfgang \& Ferracuti, 1967). Bannon (1976) and Westley (1970) also introduced the premise of negative, mutual feelings between the police and the public.

Although these broad theoretical perspectives are essential for understanding some of the underlying factors regarding assaults on police, there is a specific personal interaction that occurs between a police officer and a potential assaulter. Consequently, such events must be studied through the lens of micro-level relations. Altercations between parties grow out of emotional, conflict situations where egos and tempers play their respective roles. During the development of these exchanges, there is a good deal of opportunity for personalities to affect the course of events. Social and psychological characteristics in both the officer and the assailant are an integral component needed to assist in explaining an assault on an officer. Most research has failed to examine psychological or attitudinal data on the part of victimized officers (e.g., Meyer et al., 1981) ${ }^{2}$; the majority of empirical investigation focuses on profiles of offenders. Information pertaining to an officer's outlook could potentially be useful in formulating an explanation of the nature of violence present in police assaults.

Some scholars posit that an officer's social/psychological characteristics may contribute to his/her victimization. Dodd (1967), Sparks, Genn, \& Dodd (1977), and Bayley \& Garofalo (1989) all argue that police officers' demeanor helps to influence violent encounters between the police and citizens (see also Hirschel, Dean, \& Lumb, 1994). It is possible that certain officers assert too much power and authority (Toch, 1992), treat people with contempt and ignore feelings of dignity or individuality (Kieselhorst, 1974), and/or overstep boundaries of acceptable police behavior by being either abusive or insulting to the assailant (Chapman, Hale, \& Meyer 1974). According to Toch (1992: 56), "the assault grows out of an interpersonal sequence in which both parties participate to some measure; it's assumed that even where the assaulter contributes most of the motivation... the officer somehow makes the nature of the contribution possible." The chance that certain types of social/psychological traits, attitudes, etc. of police officers might actually precipitate an attack must be considered.

\section{Challenging the Monolithic Police Culture}

Conventional wisdom characterizes officers as adhering to a police subculture, a distinct social subgroup with a particular set of shared attitudes, values, and informal norms. 
In fact, most textbooks or comprehensive discussions of the police make some mention of the police subculture. The differentiation between the police, as a cohesive whole, and the general public is thought to exist due to the mechanisms used by officers to cope with the strains of their occupational and organizational environments (Rubenstein, 1972; Skolnick, 1966; Westley, 1970). Due to the nature of their job, officers are theorized to possess certain psychological characteristics that make up the "police personality" (see Worden, 1995). Such traits include aggressiveness, cynicism, conservatism, and authoritarianism.

This concept of a single, coherent occupational culture has been challenged by an alternative conceptualization suggesting diversity, variation, and contrast within the police organization and occupation (Fielding, 1988; Haarr 1997). A substantial and growing body of research has demonstrated that police are no longer as monolithic as earlier proposed. Data from qualitative (Haarr, 1997) and ethnographic observations of police departments (Herbert, 1998), quantitative (Paoline, Myers, \& Worden, 2000), and mixed methods studies (Jermier, Slocum, Fry, \& Gaines, 1991) reveal much attitudinal heterogeneity among officers. Of course, this idea of police culture being more complex and less psychologically homogenous than previously believed is not new. Studies based off of field research dating back to the 1970s show that officers differed in their perceptions of the police role and in their attitudes toward legal restrictions, legal institutions, discretionary enforcement, police supervision, and the citizenry (Worden, 1995).

One could reasonably expect even greater variation among officers' attitudes/outlooks in modern day policing. Starting in the 1970s/80s and continuing to present day, police departments have experienced greater diversity with the addition of more female, minority, and college educated officers to their ranks (Britz, 1997; Haarr, 1997; Walker, 1985). Take college education for example. Relatively recent studies illustrate the positive impact that a college education may have on an officer's attitude and occupational performance. Telep (2011) found that officers with bachelor's degrees held attitudes that were less supportive of the abuse of authority. Meanwhile, Rydberg \& Terrill (2010) observed college educated officers being significantly less likely to use force (i.e. less aggressive) than their non-college educated counterparts. The implementation of community policing strategies throughout the last few decades could have contributed to diversifying police departments' working environments as well.

A number of typologies have emerged with the primary goal of highlighting the variation among officers (e.g., Broderick, 1977; Brown, 1981; Muir, 1977; White, 1972). Each distinguishes officers based upon their attitudes toward both police work and the public. Two of these typologies are worth noting. Brown's (1981) typology focuses on the priority with which officers place law enforcement functions. According to the author, there are differences in an officer's aggressiveness and selectivity of enforcement; some officers represent the "old-school crime fighter" and others are more in line with the "service-style" officer. On the other hand, Muir's (1977) typology hinges on officers' views of human nature. A police officer can either identify as an "enforcer", heavily subscribing to the "us vs. them" outlook, or as a "professional/reciprocator", making him/her more receptive to working with citizens. In sum, these typologies reflect individualism and differences in an officer's role orientations.

\section{Policing Styles and Officers' Perceptions}

It is safe to assume that policing strategies differ. Two distinct styles include aggressive crime control and community policing. ${ }^{3}$ Indeed, James Q. Wilson (1968) noted that departments vary on the extent to which they emphasize law enforcement functions as opposed to the general provision of services and vice versa. There is sound reason to believe these two different styles of law enforcement affect various aspects of policing, specifically police-community relationships and interactions with the public. Aggressive law enforcement/crime control has been shown to erode police-community relations as well as the perceived legitimacy the citizens have toward officers (Cole, 1999; Greene, 1999; Hemmens \& Levin, 2000; Innes, 1999; Kennedy, 1997; Sampson \& Bartusch, 1998; Stoutland, 2001). Community policing strategies, alternatively, are intended to improve the dynamic working environment between officers and the public they serve (Cordner, 1997; Eck \& Rosenbaum, 1994; Greene, 2000). The impact of policing strategies/styles may extend further to outcomes like assaults on officers. A thorough examination of the literature reveals that the influence of policing styles on officer victimization has been largely overlooked by researchers (for a review, see Kaminski, 2004; Kaminski et al., 2003). 
One study, in particular, attempted to answer Kaminski \& colleagues' call to research. Wilson \& Zhao (2008) explored the impact of two contemporary styles of policing identified from past studies, community policing and aggressive law enforcement, on officer injuries. The authors used data from the LEOKA survey to assess officer victimization at the department level and the Law Enforcement Management and Administrative Statistics (LEMAS) to measure a particular agency's dedication to community policing. Among the departments in the sample, those agencies who met with a large number of community groups experienced smaller rates of injurious assaults than did agencies that met with fewer such groups. This finding suggests the community policing orientation might lead to less violence being used against officers.

The abovementioned study is a good first step into the inquiry of whether policing styles influence assaults on police officers. There are, however, a few limitations worth discussing. LEOKA data are reported in the aggregate form (i.e. the unit of analysis is at the department level), thus, making it impossible to determine specific risk factors for individual officers (Rabe-Hemp \& Schuck, 2007). More specifically, researchers cannot assess the impact of different individual and situational factors on the likelihood of assaults. It is unlikely that every police officer in an agency will possess an identical occupational outlook. Much variation is to be expected.

Walker \& Katz (1995) raise important questions about the validity and reliability of the LEMAS data. The authors identified and sought out police departments who reported possessing special bias crime units in the LEMAS survey, inquiring about each department's actual commitment to such units. Surprisingly, they found that more than one-third (37.5\%) of the departments that LEMAS reported as having a special bias crime units had, in reality, made no organizational commitment to the issue of bias crime enforcement. As can be seen, it is unknown whether a departmental policy represents, or will materialize into, actual practice for the boots on the ground. This study highlights the call for additional research on the validity and reliability of other data reported in LEMAS, such as the commitment to community policing. Self-report questionnaires at the individual-level may be a more accurate way to measure an officer's personal commitment to either community policing or law enforcement duties.

\section{Current Focus}

The purpose of the present research is to extend this type of study to individual police officers. Inspired by the work challenging the monolithic police culture and affirming officers' attitudinal heterogeneity, the current study's goal is to test whether the influences of either aggressive law enforcement or community policing ideologies contribute to police victimization. Does an officer's perception of his/her occupational role (i.e. crime control vs. public service) and attitude/opinion towards citizens influence the likelihood of on the job assault? Two hypotheses are introduced:

$H_{1}$ : Officers who identify more with the crime control paradigm, as opposed to public service, will be more likely to be assaulted on the job.

$\mathrm{H}_{2}$ : Officers who negatively view the public they serve will be more likely to be assaulted on the job.

\section{Methods}

\section{Data}

This study focused exclusively on officers serving in patrol divisions. Patrol officers spend the majority of their job interacting with citizens, putting them in a position to be the most at-risk group for potential assault (Bannon, 1976; FBI, 2012a; Geller \& Karales, 1981; Hirschel et al., 1994). Individual-level data were compiled using a cross-sectional survey questionnaire, approved by a university Institutional Review Board, during the spring of 2012. The questionnaires were administered to municipal police officers from eight departments throughout four counties in the state of New Jersey. Chiefs of police granted the authors permission to survey their respective departments. The first author then attended roll-calls in each of the eight departments under study, similar to the methods used by other scholars to collect individual-level officer data (e.g., Chappell \& Piquero, 2004). Although both day and night shifts for each department were included in the sample, there was not an opportunity to survey every possible shift. Of all the patrol officers that we had the fortune of seeing, it is estimated that a response rate of approximately $60 \%$ was achieved. The final sample numbered 133 officers. ${ }^{4}$ 
The eight departments varied in terms of size. Two of the departments were made up of less than 20 sworn law enforcement officers, four departments consisted of between 20 and 50 officers, and two departments were comprised of over 150 officers. Similarly, the population of each municipality mirrored the size its police force. According to the 2010 U.S. Census, two departments served populations under 10,000 people, four departments served populations from 10,000-50,000 people, and two departments served populations over 90,000 people (U.S. Census Bureau, 2011).

\section{Measures}

Prior to data collection, the authors consulted with law enforcement professionals during the construction of the items to be used in the survey. One retired and two current chiefs of police reviewed the prospective questions and provided valuable feedback. The goal of this inquiry was to increase the construct validity of the variables, especially the independent variables.

\section{Dependent Variable}

The outcome variable of interest is the self-reported assault on the officer. Following prior research, assault was conceptually defined as, "Any overt act that an officer perceives or has reason to believe was intended to cause him/her harm" (Chapman, Swanson, \& Meyer, 1974; Kaminski \& Sorensen, 1995; Meyer et al., 1981; Uchida, Brooks, \& Kopers, 1987). This definition was provided to officers in the survey questionnaire immediately before being asked, "Have you ever been physically assaulted while performing your job duties?" then instructed to record the number of times such events occurred throughout their careers, allowing for an interval/ratio level of measurement. Physical assaults are salient experiences; therefore, it is reasonable to assume that the officers in the study were capable of reliably and accurately recalling the frequency with which they had been victimized. The upper limit of responses was truncated at 11+ assaults to help secure a normal distribution and avoid skewness. Thirty officers (23\%) reported that they had never been assaulted in the line of duty, while the majority of officers in the sample $(77 \% ; n=103)$ reported that they had been assaulted at least once $($ mean $=$ 4.12).

\section{Independent Variables}

Beliefs, attitudes, and values can be estimated quantitatively. Researchers have treated officer outlooks as independent variables in the past (e.g., Jermier et al., 1991; Paoline et al., 2000; Worden, 1995). Most research on police officers' subjective outlooks is based on those officers' coded responses to survey questionnaires. Using these independent variables, scholars can attempt to predict officer behavior or other outcomes. We constructed our independent variables based off of items used in previous work (e.g., Paoline et al., 2000).

Officer's perception of his/her occupational role. The first independent variable is concerned with how an officer views his or her job function. Does an officer identify more with crime control or public service? A single item indicator was used to measure an officer's perception of his/her occupational role. Participants read the statement, "The majority of time on the job should be spent doing real police work and not on other service roles." They were then asked to respond to a 0 (strongly disagree) to 10 (strongly agree) point continuum scale using one point increments (mean $=4.81$ ). Higher values signify an officer identifying more with the crime control function, whereas lower values denote an officer identifying more with the public service function.

Officer's attitude/opinion towards citizens. The second independent variable is designed to determine how an officer views the public/citizenry that he or she serves. Does an officer perceive citizens as cooperative or as distrustful? A four item summated scale was used to measure an officer's attitude/opinion toward citizens. Participants read four statements and were instructed to respond to four point scale: 1 (strongly disagree) to 4 (strongly agree). The items included: "Police officers have reason to be distrustful of most citizens," "The public is generally unappreciative of the work that police officers perform," "Often times, I feel distanced from the community I serve," and "Generally, I find it easy to cooperate with citizens" (reverse coded). An acceptable level of internal consistency (Cronbach's alpha $=0.67$ ) was achieved. ${ }^{6}$ Higher values suggest an officer perceives the public in a negative light, where lower values indicate an officer sees the public in a more positive light. Descriptive statistics for each of the variables included in the study can be found in Table 1.

\section{Controls}

A number of control variables were introduced to ensure ceteris paribus and rule out spuriousness. One control is the length of one's career as a law enforcement officer. 
With more experience on the job comes more opportunity to be victimized. Participants filled in the number of years that they have served as a police officer. Career length ranged from a less than one year to 39 years (mean $=14)$.

As previously mentioned, an emerging body of literature has displayed the potentially positive impact of higher education on police-related outcomes. According to contemporary education research, the college experience puts people in the position to interact with others from different backgrounds while improving their interpersonal communication and analytical skills (e.g., Feldman \& Newcomb, 1994; Pascarella \& Terenzini, 2005). It is possible that such skills allow an officer to better handle situations and solve them verbally. Hence, we controlled for an officer's level of education. Participants were asked to report their highest level of educational attainment. The response mode included five categories: "high school diploma/GED" (13\%; $n=17)$, "some college" $(19 \% ; n$ $=25)$, "associates degree" $(11 \% ; n=14)$, "bachelors degree" $(44 \% ; n=58)$, and "masters/law degree" $(14 \% ; n=$ 19).

Research also suggests that community-level factors are related to police violence (e.g., Jacobs \& Carmichael, 2002; Kaminski et al., 2003). The impact of city-level crime and violence was assessed using violent and property crime rates for each of the municipalities in the study. In order to do so, the 2011 UCR was used to gather the number of both violent and property offenses known to law enforcement (FBI, 2012b). Since the UCR only reports these two categories in frequencies, both violent and property crime rates for each municipality had to be calculated. This was achieved by first dividing the total number of violent crimes in a town/city by the size of the town/city's population (U.S. Census Bureau, 2011), then by multiplying each rate by 1,000 (Bachman \& Paternoster, 2009):

(\# of violent crimes reported to the police/population) / 1,000 = municipality's violent crime rate

Violent crime rates for the municipalities under study ranged from 0.10 to 1.51 (mean =1.17). The same procedure was used to calculate the property crime rates; these rates ranged from 5.06 to $28.99($ mean $=19.76)$.

Table 1 - Descriptive Statistics

\begin{tabular}{l|lll}
\hline & Range & Mean & Std. Dev. \\
\hline $\begin{array}{l}\text { Physical Assault } \\
I V s\end{array}$ & $0-11+$ & 4.12 & 3.98 \\
$\begin{array}{l}\text { Perception of Occ. Role } \\
\text { a }\end{array}$ & $0-10$ & 4.81 & 2.31 \\
$\begin{array}{l}\text { Attitude/Opinion } \\
\text { Towards Citizens }\end{array}$ & $0-4$ & 2.31 & 0.70 \\
$\begin{array}{l}\text { Controls } \\
\text { Years as a Police Officer }\end{array}$ & $<1-39$ & & \\
$\begin{array}{l}\text { Level of Education } \\
\text { City/Town's }\end{array}$ & HS/GED - Masters/Law & N/A & 7.17 \\
Crime Rate & $0.10-1.51$ & 1.17 & N/A \\
$\begin{array}{l}\text { City/Town's Property } \\
\text { Crime Rate }\end{array}$ & $5.06-28.99$ & 19.76 & 0.30 \\
\hline
\end{tabular}

$\mathrm{a}=$ Higher values signify identifying more with aggressive law enforcement/crime control

$\mathrm{b}=$ Higher values signify a more negative attitude/opinion towards citizens

\section{Potential Data Limitations}

It is important to acknowledge a few of the ways in which the data used in the current study are potentially limited. One concern is generalizability. 
Because the sample consists of officers employed in only eight police departments, we cannot easily generalize the findings to larger populations such as all New Jersey municipal police officers. In an effort test the hypotheses using a small unit of analysis and given the difficulty of obtaining individual-level data, it was tough to obtain a more representative sample. Still, care should be taken while considering the broader implications of the reported findings until other studies, using samples from different geographic regions, can be conducted.

Secondly, the methods used to collect the data impeded our ability to gather a rich dataset. As previously mentioned, officers filled out surveys immediately following roll-call, before departing from the station to begin their shifts. Prior to data collection, we were instructed by a few chiefs that the officers would be restricted by time limits in an effort to get out onto the streets. Therefore, it was necessary to keep the surveys short in order to meet this demand. Unfortunately, the questionnaire did not include items for officer demographics like age, race, or gender. Some may view this as potential limitation; however, prior research consistently shows that such characteristics are often unrelated in explaining the etiology of assaults on police (Bannon, 1976; Kaminski \& Sorenson, 1995; Rabe-Hemp \& Schuck, 2007; Uchida et al., 1989).

\section{Analytic Strategy}

A number of data diagnostics were performed before conducting the analysis. Frequency analyses and skewness tests revealed that all the variables in the study were normally distributed. Zero-order correlations were run as a check for collinearity, and results can be found in Table 3 (see Appendix A). Multicollinearity was not an issue. Given that the dependent variable was measured at the interval/ratio level and normally distributed, an ordinary least squares (OLS) regression equation was run.

\section{Appendix A: Table 3 - Correlation Matrix}

\begin{tabular}{|c|c|c|c|c|c|c|c|}
\hline & $\begin{array}{l}\text { Physical } \\
\text { Assault }\end{array}$ & $\begin{array}{l}\text { Perception } \\
\text { of Occ. } \\
\text { Role }\end{array}$ & $\begin{array}{l}\text { Attitude/Opinion } \\
\text { Towards } \\
\text { Citizens }\end{array}$ & $\begin{array}{l}\text { Years } \\
\text { as a } \\
\text { Police } \\
\text { Officer }\end{array}$ & $\begin{array}{l}\text { Level of } \\
\text { Education }\end{array}$ & $\begin{array}{l}\text { City/Town's } \\
\text { Violent } \\
\text { Crime Rate }\end{array}$ & $\begin{array}{l}\text { City/Town's } \\
\text { Property } \\
\text { Crime Rate }\end{array}$ \\
\hline Physical Assault & 1.00 & & & & & & \\
\hline $\begin{array}{l}\text { Perception of } \\
\text { Occ. Role }\end{array}$ & 0.21 & 1.00 & & & & & \\
\hline $\begin{array}{l}\text { Attitude/Opinion } \\
\text { Towards } \\
\text { Citizens }\end{array}$ & 0.17 & 0.32 & 1.00 & & & & \\
\hline $\begin{array}{l}\text { Years as a } \\
\text { Police Officer }\end{array}$ & 0.32 & -0.20 & -0.17 & 1.00 & & & \\
\hline $\begin{array}{l}\text { Level of } \\
\text { Education }\end{array}$ & -0.24 & 0.02 & 0.12 & -0.15 & 1.00 & & \\
\hline $\begin{array}{l}\text { City/Town's } \\
\text { Violent Crime } \\
\text { Rate }\end{array}$ & 0.08 & 0.16 & -0.02 & -0.03 & -0.03 & 1.00 & \\
\hline $\begin{array}{l}\text { City/Town's } \\
\text { Property Crime } \\
\text { Rate }\end{array}$ & -0.23 & 0.08 & -0.04 & -0.17 & 0.32 & 0.08 & 1.00 \\
\hline
\end{tabular}

\section{Results}

The intention of the analysis was to determine whether an officer's outlook regarding both the job and the citizens influenced the likelihood of assault. Table 2 displays the findings from the OLS regression. Given the small sample size of 133, we used an alpha level of 0.05 . 
The full model reveals an R-square of $0.273(\mathrm{~F}=0.000) ; 27.3 \%$ of the variance in the dependent variable can be explained by the model. An R-square of this magnitude is relatively high in social science applications.

Our first hypothesis tested the relationship between an officer's perception of his/her occupational role and physical assault. Results show that our research hypothesis was supported. Officers who identified more with the aggressive law enforcement/crime control paradigm were more likely to experience assaults on the job, compared to those officers who identified more with the public service function. For each one unit increase in an officer's subjective outlook towards aggressive law enforcement/crime control, there was a 0.205 (beta) increase in frequency of physical assaults - net of controls. This relationship was statistically significant with a p-value of 0.019 .

The second hypothesis tested the relationship between an officer's attitude/opinion towards citizens and physical assault. Results show that this research hypothesis was supported as well. Officers who viewed the public in a more negative light were more likely to experience assaults. For each one unit increase in an officer's negative attitude/opinion towards the public, there was a 0.190 (beta) increase in the frequency of victimization - net of controls. This relationship was also statistically significant with a p-value of 0.027 . It is important to note that small sample sizes result in low statistical power to detect relationships. Due to the fact that this study was made up of a sample of only 133 officers, the findings of statistically significant relationships between both independent variable and physical assault is even more impressive

Table 2 - OLS Regression

\begin{tabular}{l|lll}
\hline & $\begin{array}{l}\text { Standardized } \\
\text { Coefficients }(\text { SE })\end{array}$ & $\boldsymbol{t}$ & Sig. \\
\hline $\begin{array}{l}\text { Perception of Occ. Role } \\
\text { a }\end{array}$ & $0.205(0.151)$ & 2.375 & $0.01 *^{*}$ \\
$\begin{array}{l}\text { Attitude/Opinion } \\
\text { Towards Citizens }\end{array}$ & $0.190(0.478)$ & 2.235 & $0.027^{*}$ \\
$\begin{array}{l}\text { Years as a Police } \\
\text { Officer }\end{array}$ & $0.345(0.045)$ & 4.154 & $0.000^{* * *}$ \\
$\begin{array}{l}\text { Level of Education } \\
\begin{array}{l}\text { City/Town's } \\
\text { Crime Rate }\end{array}\end{array}$ & $-0.158(0.265)$ & -1.869 & 0.064 \\
$\begin{array}{l}\text { City/Town's Property } \\
\text { Crime Rate }\end{array}$ & $-0.148(0.047)$ & 1.053 & 0.295 \\
\hline $\mathbf{n = 1 3 3}$ & & -1.729 & 0.087 \\
\hline
\end{tabular}

$\mathrm{a}=$ Higher values signify identifying more with aggressive law enforcement/crime control

$\mathrm{b}=$ Higher values signify a more negative attitude/opinion towards citizens

$*=\mathrm{p}<0.05 ; * * * \mathrm{p}<0.001$

Aside from testing the two hypotheses, there are a few other findings worth noting. Zero-order correlations (see Appendix A) depict a moderate relationship between the independent variables $(r=0.32 ; \mathrm{p}=0.000)$. Officers who adhere more to the aggressive law enforcement/ crime control paradigm were more likely to negatively view the public they serve, whereas officers who perceive their occupational roles to be more in line with the public service function were more likely to have positive attitudes/opinions towards citizens. In addition, results from the main model in Table 2 may provide additional evidence for the positive effects of higher education on policing outcomes. Officers in the sample with higher levels of education were less likely to be assaulted (beta $=$ $-0.158)$, net of controls. This relationship was marginally significant at the 0.05 alpha level $(p=0.064)$. 


\section{Discussion}

A substantial number of law enforcement officers are assaulted each year in the United States. The consequences stemming from these victimizations stretch far beyond the initial physical contact between the officer and assailant. Each assault not only impacts the victimized officer but also his/her family, the entire department, and police-community relationships. Moreover, such events can have lingering effects long after an assault has occurred. Assaults have been shown to lower morale, threaten individual authority and situational control, and lead to major job-related stress (see Kaminski \& Sorenson, 1995). Currently, there are many unknown factors that likely influence assaults on police officers. Any inquiry into the underlying causes or correlates of assaults is a step forward in potentially reducing or even preventing violence against the police.

This research endeavor was an attempt to uncover some of the elements that might help to predict assaultive behavior against officers. Inspired by the work of a number of scholars proposing that an officer's social/psychological characteristics may lead to his/her victimization (e.g., Bayley \& Garofalo, 1989; Toch, 1992), the purpose of this study was to examine whether the influences of either aggressive law enforcement or community policing ideologies contribute to an officer's victimization. Both an officer's perception of his/her occupational role and attitude/opinion towards citizens were found to be correlated with police victimization. Police officers' subjective outlooks regarding their job function as well as the public may play a paramount role in their demeanor during exchanges with citizens. Moreover, officer perceptions may affect the direction of interactions, leading to escalation or peaceful resolve.

These findings are highly relevant to the practical world of policing. Results provide support for another positive outcome deriving from an emphasis on community policing. Most departments have an explicit community policing policy or address this innovative strategy in their mission statements. It is, however, unclear if there is a true organizational commitment to such a policy. If a department genuinely wants to practice community policing, support must start with the chief and others in leadership positions to stress this type of working philosophy. Sergeants and shift commanders must also "buy in" to community policing and advocate its utility to the rank and file patrol officers.

The improvement of police-citizen relationships builds off of a department's greater emphasis on community policing. Again, these relations can best be fostered when officers proactively seek out community organizations and members to work together towards a unified goal. Enhanced police-community partnerships could work in both ways, helping to assuage officers' negative feelings for citizens (e.g., alienation) and making the public more appreciative of the work that police officers perform. This represents a win-win situation for all parties involved.

Future research should continue to examine assaults on police officers at the individual-level, focusing on the characteristics, outlooks, etc. of victimized officers as well as their assailants. Surveying or qualitatively interviewing both parties after a violent confrontation could provide a more complete picture and a clearer window into how confrontations escalate into physicality. Interactions, negative responses from the public, and assaults on police officers can be studied through the lens of procedural justice and Tyler's (1990) process-based model of regulation. It is plausible that exchanges intensify and emotions heighten when citizens perceive that they are being treated unfairly/unjustly. Scholars should also make use of advanced research designs and statistical analyses such as hierarchical linear and nonlinear modeling (HLM). After all, police officers are nested within departments, and officer-citizen encounters/relations are further nested within communities. Advancing this body of work is essential to elevate the safety of our men and women in blue.

\section{Notes}

$1=$ Each year, the FBI releases the Law Enforcement Officers Killed and Assaulted (LEOKA) report as part of its Uniform Crime Report. The statistics/information from a particular year is usually announced to the public via the FBI's website around October of the following year. The 2011 LEOKA is currently the most recent report.

$2=$ Meyer et al. (1981) note a deficiency in their analysis. The authors state that psychological and attitudinal data for the officers were not gathered.

3 = Some scholars believe the division between law enforcement and order maintenance functions is often overdrawn (e.g., Herbert, 1998). This leaves two primary styles of policing: law enforcement and community policing.

$4=$ The number of officers from each department in the sample is proportional to the sizes of the departments. In other words, a higher number of officers from the larger departments participated relative to the number of 
officers taking part in smaller departments. For example, 34 and 39 officers are included from the departments with 150+ officers. Moreover, 16, 18, 9, and 7 officers are from departments with between 21-50 officers. Lastly, there are 7 and 3 officers from the two departments with less than 20 officers.

$5=$ Officers were asked the number of times that they had "ever" been assaulted because such events do not occur very frequently. It was feared that if the participants were asked to record the number of times they had been assaulted in the last year or so, there would not be enough variation to perform statistical analyses.

$6=$ Green, Lissitz, \& Mulaik (1977) reveal that alpha levels increase as the number of items in the scale increases. Given the smaller number of items in this scale (4), the alpha is appropriate and acceptable.

\section{References}

Bachman, R., \& Paternoster, R. (2009). Statistical methods for criminology and criminal justice. $\quad\left(3^{\text {rd }}\right.$ ed.). New York: McGraw-Hill.

Bannon, J. D. (1976). Assaults on police officers: A sociological study of the definition of the situation. Unpublished doctoral dissertation, Wayne State University.

Bayley, D. H., \& Garofalo, J. (1989). The management of violence by police patrol officers. Criminology, 27, 125.

Boylen, M., \& Little, R. E. (1990). How criminal justice theory can aid in our understanding of assault on police officers. Police Journal, 63, 208-215.

Brandl, S. G., \& Stroshine, M. S. (2012). The physical hazards of police work revisited. Police Quarterly, 15, 262-282.

Britz, M. T. (1997). The police subculture and occupational socialization: Exploring individual and demographic characteristics. American Journal of Criminal Justice, 21, 127-146.

Broderick, J. J. (1977). Policing in a time of change. Morristown, NJ: General Learning Press.

Brown, M. K. (1981). Working the street: Police discretion and the dilemmas of reform. New York: Russell Sage Foundation.

Chapman, S. G., Hale, C. D., \& Meyer, C. K. (1974). Perspectives on police assaults in the south central United States, 1-3. Norman, OK: University of Oklahoma Bureau of Government Research.

Chapman, S. G., Swanson, C. G., \& Meyer, K. C. (1974). A descriptive profile of the assault incident. Norman, OK: University of Oklahoma Bureau of Government Research.

Chappell, A. T., \& Piquero, A. R. (2004). Applying social learning theory to police misconduct. Deviant Behavior, 25, 89-108.

Cole, D. (1999). No equal justice: Race and class in the American criminal justice system. New York: The New Press.

Cordner, G. W. (1997). Community policing: Elements and effects. In R. G. Dunham \& G. P. Alpert (Eds.), Critical issues in policing: Contemporary readings $\left(5^{\text {th }}\right.$ ed. pp. 401-418). Prospect Height, IL: Waveland Press.

Dodd, D. J. (1967). Police mentality and behavior. Issues in Criminology, 3, 47-67.

Eck, J., \& Rosenbaum, D. (1994). The new police order: Effectiveness, equality and efficiency in community policing. In D. Rosenbaum (Ed.), The challenge of community policing: Testing the promises (pp. 3-23). Thousand Oaks, CA: Sage.

Federal Bureau of Investigation. (2012a). Law enforcement officers killed and assaulted, 2011. Retrieved from http://www.fbi.gov/about-us/cjis/ucr/leoka/2011

Federal Bureau of Investigation. (2012b). Offenses known to law enforcement, by state by city, 2011. Retrieved from http://www.fbi.gov/about-us/cjis/ucr/crime-in-the-u.s/2011/crime- in-the-u.s.-2011/offensesknown-to-law-enforcement/

Feldman, K. A., \& Newcomb, T. M. (1994). The impact of college on students. New Brunswick, NJ: Transaction Publishers.

Fielding, N. G. (1988). Joining forces: Police training, socialization, and occupational competence. New York: Routledge.

Geller, W. A., \& Karales, K. J. (1981). Split-second decisions: Shootings of and by Chicago police. Chicago: Chicago Law Enforcement Study Group. 
Green, S., Lissitz, R., \& Mulaik, S. (1977). Limitations of coefficient alpha as an index of test unidimensionality. Educational and Psychological Measurement, 37, 827-838.

Greene, J. A. (1999). Zero tolerance: A case study of police policies and practices in New York City. Crime and Delinquency, 45, 171-187.

Greene, J. R. (2000). Community policing in America: Changing the nature, structure, and function of the police. In J. Horney (Ed.), Policies, processes and decisions of the criminal justice system. Criminal justice, 2000 (pp. 299-370). Washington, DC: U.S. Government Printing Office.

Haarr, R. N. (1997). Patterns of interaction in a police patrol bureau: Race and gender barriers to integration. Justice Quarterly, 14, 53-85.

Hemmens, C., \& Levin, D. (2000). Resistance is futile: The right to resist unlawful arrest in an era of aggressive policing. Crime and Delinquency, 46, 472-496.

Herbert, S. (1998). Police subculture reconsidered. Criminology, 36, 343-369.

Hirschel, J. D., Dean, C. W., \& Lumb, R. C. (1994). The relative contribution of domestic violence to assault and injury of police officers. Justice Quarterly, 11, 99-117.

Innes, M. (1999). 'An iron fist in an iron glove?' The zero tolerance policing debate. The Howard Journal, 38, 397-410.

Jacobs, D., \& Carmichael, J. T. (2002). Subordination and violence against state control agents: Testing political explanations for lethal assaults against the police. Social Forces, 80, 1223-1251.

Jermier, J. M., Slocum, J. W., Fry, L. W., \& Gaines, J. (1991). Organizational subcultures in a soft bureaucracy: Resistance behind the myth and façade of an official culture. Organization Science, 2, 170-194.

Kaminski, R. J. (2004). The murder of police officers. New York: LFB Scholarly.

Kaminski, R. J., Jefferis, E., \& Gu, J. (2003). Community correlates of serious assaults on police. Police Quarterly, 6, 119-149.

Kaminski, R. J., \& Sorensen, D. W. M. (1995). A multivariate analysis of individual, situational and environmental factors associated with police assault injuries. American Journal of Police, 14, 3-48.

Kennedy, R. (1997). Race, crime and the law. New York: Vintage.

Kieselhorst, D. C. (1974). A theoretical perspective of violence against police. Norman, OK: University of Oklahoma Bureau of Government Research.

Maguen, S., Metzler, T. J., McCaslin, S. E., Inslicht, S. S., Henn-Haase, C., Neylan, T. C., \& Marmar, C. R. (2009). Routine work environment stress and PTSD symptoms in police officers. The Journal of Nervous and Mental Disease, 197, 754-760.

Manning, P. K. (1980). Violence and the police role. The Annals of the American Academy of Political and Social Science, 452, 135-144.

Meyer, C. K., Magedanz, T. C., Dahlin, D. C., \& Chapman, S. G. (1981). A comparative assessment of assault incidents: Robbery-related, ambush, and general police assaults. Journal of Police Science and Administration, 9, 1-18.

Meyer, C. K., Magedanz, T. C., Kieselhorst, D. C., \& Chapman, S. G. (1979). Violence and the police. Journal of Police Science and Administration, 7, 161-171.

Miller, W. B. (1958). Lower-class culture as a generating milieu of gang delinquency. The Journal of Social Issues, 14, 5-19.

Muir, W. K. (1977). Police: Streetcorner politicians. Chicago: University of Chicago Press.

Muir, W. K. (1980). Power attracts violence. The Annals of the American Academy of Political and Social Science, 452, 48-52.

Pascarella, E. T., \& Terenzini, P. T. (2005). How college affects students: Findings and insights from twenty years of research. San Francisco: Jossey-Bass.

Paoline, E. A., Myers, S. E., \& Worden, R. E. (2000). Police culture, individualism, and community policing: Evidence from two departments. Justice Quarterly, 17, 575-605.

Rabe-Hemp, C. E., \& Schuck, A. M. (2007). Violence against police officers: Are female officers at greater risk? Police Quarterly, 10, 411-428.

Rubenstein, J. (1972). City police. New York: Farrar, Straus, and Giroux.

Rydberg, J., \& Terrill, W. (2010). The effect of higher education on police behavior. Police Quarterly, 13, 92120. 
Sampson, R. J., \& Bartusch, D. J. (1998). Legal cynicism and (subcultural?) tolerance of deviance:The neighborhood context of racial differences. Law and Society Review, 32, 777-804.

Sherman, L. W. (1980). Perspectives on police and violence. The Annals of the American Academy of Political and Social Science, 452, 1-12.

Skolnick, J. (1966). Justice without trial: Law enforcement in a democratic society. New York: Wiley.

Sparks, R. F., Genn, H. G., \& Dodd, D. J. (1977). Surveying victims: A study of the measurement of criminal victimization, perceptions of crime, and attitudes to criminal justice. New York: Wiley.

Stoutland, S. E. (2001). The multiple dimensions of trust in resident/police relations in Boston. Journal of Research in Crime and Delinquency, 38, 226-256

Telep, C. W. (2011). The impact of higher education on police officer attitudes toward abuse of authority. Journal of Criminal Justice Education, 22, 392-419.

Tyler, T.R. (1990). Why people obey the law. Princeton, NJ: Princeton University Press.

Toch, H. (1992). Violent men: An inquiry into the psychology of violence (4 ${ }^{\text {th }}$ ed.). Washington, DC: American Psychological Association.

Uchida, C. D., Brooks, L. W., \& Kopers, C. S. (1987). Danger to police during domestic encounters: Assaults on Baltimore county police, 1984-86. Criminal Justice Policy Review, 2, 357-371.

U.S. Census Bureau. (2011). 2010 census interactive population search. Retrieved from http://2010.census.gov/2010census/ipmtext.php?fl=34.

Walker, S. (1985). Racial minority and female employment in policing: The implications of "glacial" change. Crime \& Delinquency, 31, 555-572.

Walker, S., \& Katz, C. M. (1995). Less than meets the eye: Police department bias-crime units. American Journal of Police, 14, 29-48.

Westley, W.A. (1970). Violence and the police: A sociological study of law, custom, and morality. Cambridge, MA: The MIT Press.

White, S. O. (1972). A perspective on police professionalization. Law \& Society Review, 7, 61-85.

Wilson, J.Q. (1968). Varieties of police behavior. Cambridge, MA: Harvard University Press.

Wilson, S., \& Zhao, J. (2008). Determining the correlates of police victimization: An analysis of organizational level factors on injurious assaults. Journal of Criminal Justice, 36, 461-468.

Wolfgang, M. E., \& Ferracuti, F. (1967). The subculture of violence: Toward an integrated theory of criminology. Beverly Hills, CA: Sage Publications.

Worden, R. E. (1995). Police officers' belief systems: A framework for analysis. American Journal of Police, 14, 49-81.

\section{BIOGRAPHICAL SKETCH}

Peter W. Liu is a professor in the Department of Criminal Justice at Monmouth University. He received his Ph.D. in Criminology from Indiana University of Pennsylvania. His work has appeared in Police Studies, Deviant Behavior, and the International Journal of Offender Therapy and Comparative Criminology.

John A. Shjarback is an assistant professor in the Department of Criminal Justice at the University of Texas at El Paso. He earned his Ph.D. in Criminology and Criminal Justice from Arizona State University. His research interests center on policing, specifically environmental and organizational influences on discretionary officer behavior and current issues and trends. His recent work has been featured in Crime \& Delinquency, Journal of Criminal Justice, Police Quarterly, and Policing: An International Journal. 